\title{
STOMATAL DEVELOPMENT IN AERIAL AXES OF PSILOTUM NUDUM (PSILOTACEAE)
}

\author{
JAMES E. MICKLE \\ Department of Plant Biology, Box 7612, North Carolina State University Raleigh, NC 27695 \\ E-mail: james_mickle@ncsu.edu
}

MARIA ROSARIA BARONE LUMAGA and PAOLO DE LUCA

Orto Botanico, Facoltà di Scienze, Università degli Studi di Napoli "Federico II," via Foria, 223, 80139 Napoli, Italy

\begin{abstract}
Apical regions of developing aerial shoots of Psilotum nudum (L.) Beauv. were studied using both scanning electron microscopy (SEM) and light microscopy (LM) with the aim of improving our understanding of early stages in stomatal and epidermal ontogenesis. SEM samples were fixed in gluteraldehyde, critical point dried, and coated with an Au-Pd alloy. LM samples were fixed in FAA and embedded in paraffin. LM sections were stained with $0.05 \%$ toluidine blue for protein. SEM shows that $P$. nudum stomata develop from $20 \mu \mathrm{m}$-long domed meristemoid cells into guard cell mother cells (GMCs). A furrow dividing guard cells develops at $30 \mu \mathrm{m}$ long, and wax deposition that will cover the entire cell begins at $70 \mu \mathrm{m}$ long. LM longitudinal sections of GMCs show a cytoplasmic protein net that organizes into radial fibers, similar to reports of actin fibers in stomata of angiosperms. This study provides additional details of stomatal development in Psilotum and is the first report of an actin-like protein net in Psilotum.
\end{abstract}

Key Words: Psilotum; stomata; stomatal development; actin-like.

\section{INTRODUCTION}

Psilotum Sw. is included, with the genus Tmesipteris Bernh., in the Psilotaceae, a family comprising rootless, eusporangiate plants sharing a series of morphological and biochemical characters (Takahashi et al. 1990). Recent studies have classified these long enigmatic plants as a sister group to the Ophioglossales and Equisetales (Schneider et al. 2009).

Morphological and ontogentic types of stomata have been repeatedly classified (Fryns-Claessens and Van Cotthem 1973; Payne 1979; Rassmussen 1981; Baranova 1987). Stomata in Psilotum are of the haplocheilic type (Pant and Mehra 1963). Haplocheilic stomata, as first described by Florin (1933) occur when a meristemoid cell [MC] acts as a guard cell mother cell [GMC] and produces the two guard cells by a direct division. Following the classifications of Fryns-Claessens and Van Cotthem (1973) and Payne (1979), Psilotum stomata belong to the perigenous type (the GMC divides once to form the two guard cells, with the surrounding epidermal cells independently derived from the protoderm) leading to anomocytic stomata (devoid of subsidiary cells).

Previous studies on stomatal development in $P$. nudum by Zimmermann (1927) illustrated later stages of guard cell development using line drawings of cross and longitudinal sections. Pant and Mehra (1963) employed epidermal peels to demonstrate that the guard cells originate from a single cell. Pant and Khare (1971) illustrated epidermal peels and cross sections of stomata mature axes, stained for lignin and cutin. They distinguish GMCs based on their smaller size and dense cytoplasmic staining of the cytoplasm and nucleus as compared to surrounding cells. Payne (1979) noted that psilopsids show rectate stomatal development. In the type of development seen in psilopsids, radial files of cells are narrow and a GMC is formed from a meristemoid cell within the file. Division of the GMC occurs at the proximal end of the cell, and division into meristemoid and GMC occurs completely across the cell from one lateral wall to the other. At maturity, the guard cells appear to link two successive epidermal cells in the file. The proximal cell is the mesogene and the distal cell is the perigene (Payne 1979).

Apical regions of developing aerial shoots of $P$. nudum (L.) Beauv. (Fig. 1) were studied using both light microscopy (LM) and scanning electron microscopy (SEM) with the aim of improving our understanding of early stages in stomatal and epidermal ontogenesis. While the general outline of stomatal development is well known for $P$. nudum, this report provides new details of these processes revealed by SEM and LM. These approaches have yielded cytological information that has not been reported previously on $P$. nudum ontogeny.

\section{MATERIALS AND METHODS}

Samples for scanning electron microscopy (SEM) were collected from plants living in the NCSU 


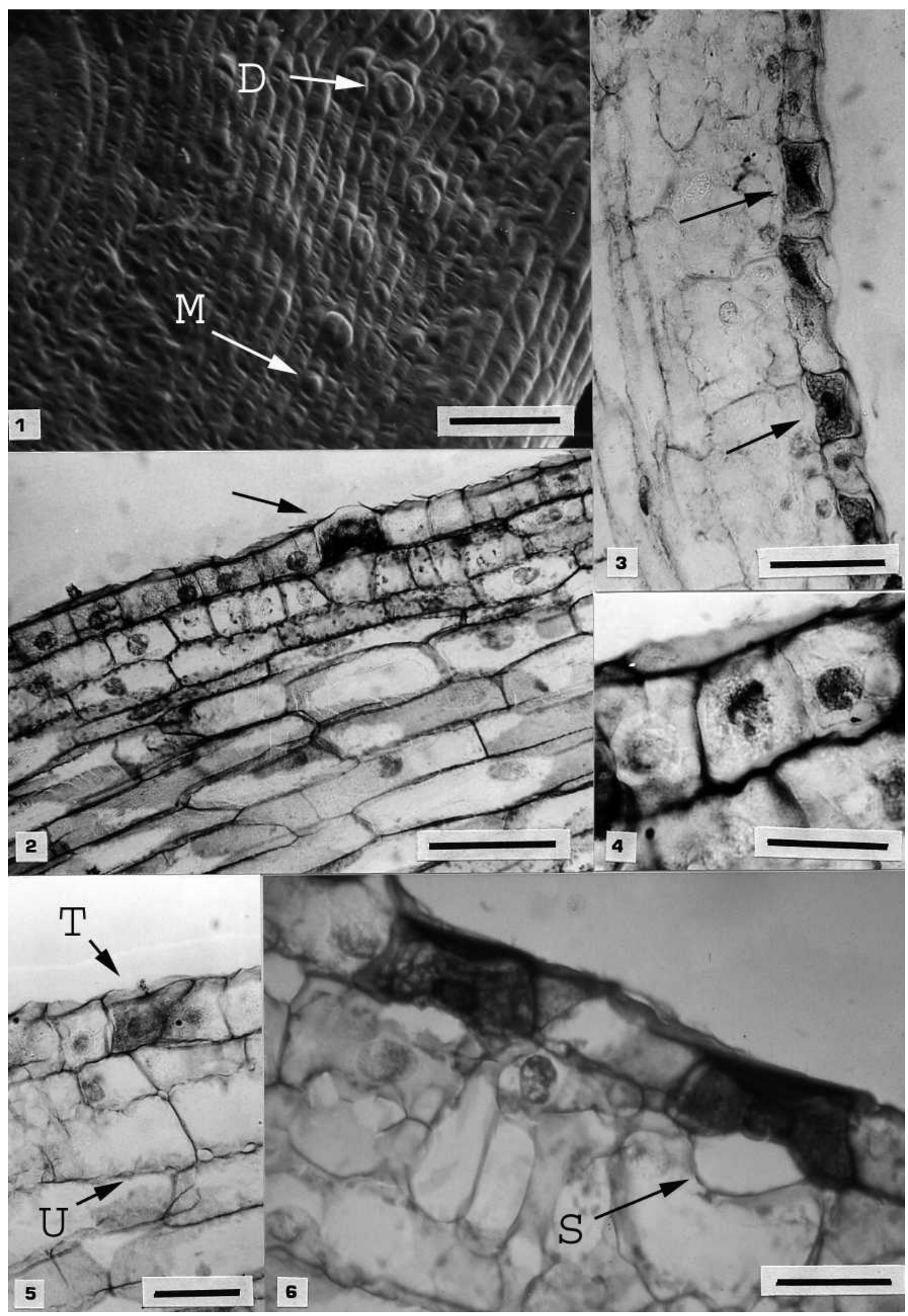

FIG. 1. Epidermis of a young aerial axis with meristemoid cells (M) and developing stomata (D). Bar $=100 \mu \mathrm{m}$.

FIG. 2. Longitudinal section showing epidermal cells and protruding cell (arrow). Bar $=100 \mu \mathrm{m}$.

FIG. 3. Longitudinal section showing developing guard cells (arrow) with the cytoplasmic net surrounding the nucleus. Bar $=100 \mu \mathrm{m}$.

FIG. 4. Metaphasic epidermal cell with oblique mitotic spindle. Bar $=50 \mu \mathrm{m}$.

FIG. 5. Epidermal cell with a trapezoidal outline. Trapezoid cells at arrow labeled T. Undulate walls of chlorenchyma cells shown at arrow labeled U. Bar $=50 \mu \mathrm{m}$

FIG. 6. Developing guard cells. Outline of a small substomatal chamber (S) is visible. Bar $=50 \mu \mathrm{m}$. 
Horticutural Greenhouse. Specimens were fixed in gluteraldehyde in phosphate buffer $(0.65 \mathrm{M}, \mathrm{pH} 7)$, and dehydrated in a graded ethanol series, critical point dried in $\mathrm{CO}_{2}$ and coated with ca. $30 \mathrm{~nm}$ gold-palladium alloy.

Samples for light microscopy (LM) were collected from plants growing in the greenhouse of the Botanical Garden (Orto Botanico) of the University of Naples (Italy), fixed in FAA, (formaline-acetic acid-alcohol: 105-50), dehydrated in a a graded ethanol series, and embedded in paraffin with a melting point of $51-53^{\circ} \mathrm{C}$. Sections $12 \mu \mathrm{m}$ thick were stained with $0.05 \%$ toluidine blue as a general protein stain.

\section{RESULTS}

As stomatal development begins, the MC and GMC are in a single narrow file of cells (Fig. 1, M). Upon maturity, the guard cells are flanked laterally by two elongate epidermal cells in files lateral to the guard cells, distally by a single epidermal cell (the MC) and proximally by two or occasionally one elongate epidermal cells (Figs. 7, 8, 11) for a total of four-five surrounding cells. Oblique mitosis (Fig. 4), leading to epidermal cells with a trapezoidal outline, is visible in longitudinal sections (Fig. 5 at T).

The first identifiable stage of stomatal development occurs at about $0.5 \mathrm{~mm}$ from the axis apex with the SEM observation of $20-\mu \mathrm{m}$ long domed guard cell mother cells (GMCs) (Fig. 1 at M). LM images of longitudinal sections of the apex show protruding cells at ca. $50 \mu \mathrm{m}$ long (Fig. 2 at arrow). Developing guard cells become clearly recognizable due to an unusual hourglass-like appearance (Fig. 6) and presence of a sub-stomatal chamber (Fig. 6 at arrow). First detection of a furrow dividing the guard cells appears when the cells are ca. $30 \mu \mathrm{m}$ long (Fig. 1 at D). Stomatal cells sink during developmental stages and mature stomata are slightly sunken on the epidermis (Figs. 6, 7, 8). Mature stomata are ca. 75-85 $\mu \mathrm{m}$ long by ca. $30 \mu \mathrm{m}$ wide (Figs. 7, 8, 11); epidermal cells are ca. 150$180 \mu \mathrm{m}$ long by $25-30 \mu \mathrm{m}$ wide (Fig. 11). Deposition of epicuticular wax that will cover the entire stomatal aperture begins in $70 \mu \mathrm{m}$ long stomata (Figs. 7, 8). The net of epicuticular wax is composed of threads $0.3 \mu \mathrm{m}$ thick (Fig. 9). (Figs. 7, 8). Epidermal cells are raised, giving the epidermal surface an overall rugose appearance (Figs. 1, 7, 8). The cellular surface of epidermal cells is smooth with epicuticular wax absent except on the stomata (Figs. 1, 7, 8).

Chlorenchyma cell walls in early developmental stages show unusual undulations (Fig. 5 at U, 6, 10 at U, 11 at $\mathrm{U})$. These cell wall undulations are more visible in cells of mature chorenchyma seen in paradermal section (Fig. 11 left and right).

Within the developing guard cells, toluidine blue stain density increases during growth (Figs. 2 at arrow, 3 and
6). Staining shows the presence of a cytoplasmic protein net surrounding the nucleus and filling nearly the entire cell (Figs. 3 at arrows and 6). The cytoplasmic net has a random appearance in some guard cells observed in longitudinal section (Fig. 3 at arrows, Fig. 6 left), while in other guard cells it has a more radial appearance (Fig. 6, right).

\section{DISCUSSION}

Past studies of stomatal development in Psilotum have been carried out principally by epidermal peels or occasionally cross sections, using light microscopy. The current study shows surface features and demonstrates the development of details, such as the division furrow and epistomatal wax, not previously illustrated. The GMC develops as a small dome that enlarges, forms a furrow, descends to develop into a slightly sunken stoma and secretes epistomatal wax. This provides a clearer picture of stomatal development in Psilotum.

The cell wall undulations of chlorenchyma underlying the epidermal dells are undoubtedly a mechanism for developing air spaces within this internal tissue. The presence of an oblique mitotic spindle probably leads to the formation of epidermal cells with a trapezoidal outline visible in the longitudinal section of the aerial axis.

The cytoplasmic net was observed after staining with toluidine blue, commonly used as a general protein stain. This net was detected only in the cytoplasm of developing guard cells but not in surrounding epidermal cells and is undoubtedly involved as an organizer of the cell morphology during the maturation of stomata. Actin is well known in several angiosperms and has been reported in a fern, Asplenium nidus (Apostolakos and Galatis 1998, 1999; Apostolakos et al. 1997), to regulate stomatal movement (Gao et al. 2008; Dzierżynska 2006) and stomatal development (Dzierżynska 2006). While genes for actin are known to occur in Psilotum (An et al. 1999), and actin has been shown to occur in developing and mature spores (Tchorzewska and Bednara 2011), the presence of actin has not been demonstrated in stomata. The protein cytoplasmic net observed in the present study is virtually identical to those observed in recent studies of stomata in angiosperms (e.g., Wang et al. 2011; Gao et al. 2008). Gao et al. (2008) showed that in closed stomata the actin microfiber arrays were randomly arrayed in a net-like pattern, while in open stomata, the microfibers were radially arrayed. The protein cytoplamic net shows both random and radial patterns that are nearly identical to those observed in angiosperms. These observations demonstrate that stomata in Psilotum are probably regulated in a manner similar to angiosperms (Dzierżynska 2006) and A. nidus (Apostolakos and Galatis 1998, 1999; Apostolakos et al. 


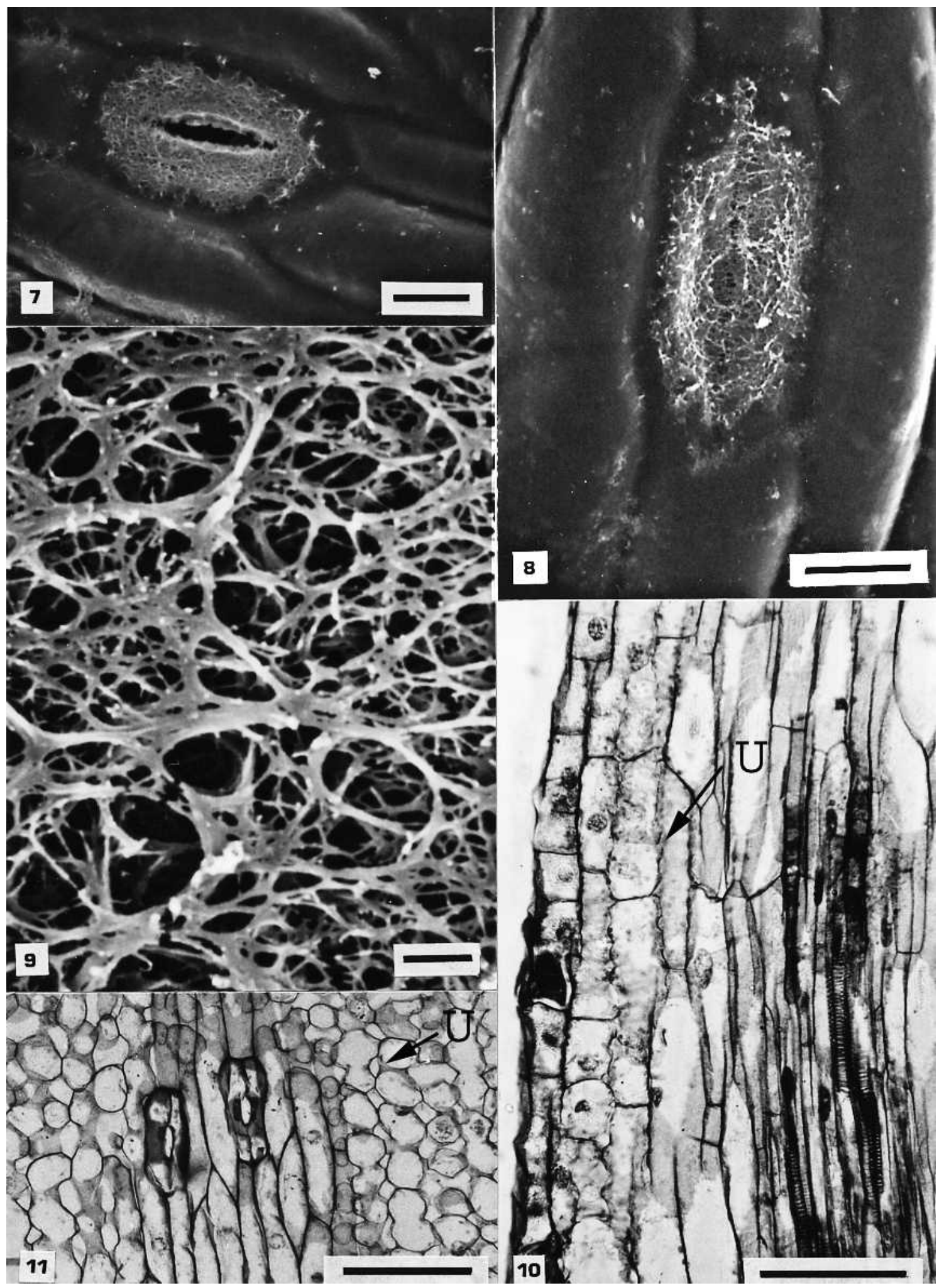

FIG. 7. Stomatal complex with epicuticular wax; the cuticular surface of epidermal surface is smooth. Bar $=20 \mu \mathrm{m}$.

FIG. 8. Stomatal complex with epicuticular wax concealing pore. Bar $=20 \mu \mathrm{m}$.

FIG. 9. Epicuticular wax composed of a network of fibers. Bar $=1 \mu \mathrm{m}$.

FIG. 10. Developing axis with differentiating vascular bundles and chlorenchyma. Undulate walls of chlorenchyma cells shown at arrow labeled U. Bar $=100 \mu \mathrm{m}$.

FIG. 11. Paradermal section of a lateral branch with mature chlorenchyma and with stomata arranged in the hollow longitudinal ribs. Undulate walls of chlorenchyma cells shown at arrow labeled U. Bar $=100 \mu \mathrm{m}$. 
1997). Additional research is required to confirm the actin nature of the protein cytoplasmic net, however, its appearance is very actin-like.

\section{LITERATURE CITED}

AN, S. S., B. MO, K. WEBER, AND D. BHATTACHARYA. 1999. The origin and evolution of green algal and plant actins. Mol. Biol. Evol. 16:275-285.

APOSTOLAKOS, P., AND B. GALATIS. 1998. Probable cytoskeleton involvement in stomatal pore formation in Asplenium nidus L. Protoplasma 203:48-57.

APOSTOLAKOS, P., AND B. GALATIS. 1999. Microtubule and actin filament organization during stomatal morphogenesis in the fern Asplenium nidus. II. Guard cells. New Phytol. 141:209-223.

APOSTOLAKOS, P., P. PANTERIS, AND B. GALATIS. 1997. Microtubule and actin filament organization during stomatal morphogenesis in the fern Asplenium nidus. I. Guard cell mother cell. Protoplasma 198:93-106.

BARANOVA, M. A. 1987. Historical development of the present classification of morphological types of stomata. Bot. Rev. 53:53-79.

DZIERZYNSKA, A. 2006. The role of cytoskeleton in stomata functioning. Acta Phys. Planta. 28:59-79.

FLORIN, R. 1933. Studien über die Cycadales des Mesozoikums nebst Erörterungen über die Spaltöffnungsapparate der Bennettitales. K. Svensk. Vet. Acad. Handl. 12:1-134.

FRYNS-CLAESSENS, E., AND W. VAN COTTHEM. 1973. A New Classification of the ontogenetic types of stomata. Bot. Rev. 39:71-138.
GAO, X., J. CHEN, P. WEI, F. REN, J. CHEN, AND X. WANG. 2008. Array and distribution of actin filaments in guard cells contribute to the determination of stomatal aperture. Plant Cell Rep. 27:1655-1665.

PANT, D. D., AND P. K. KHARE. 1971. Epidermal structure of Psilotales and stomatal ontogeny of Tmesipteris tannensis Bernh. Ann. Bot. 35:151-157.

PANT, D. D., AND B. MEHRA. 1963. Development of stomata in Psilotum nudum (L.) Beauv. Curr. Sci. 32:420-422.

PAYNE, W. W. 1979. Stomatal Patterns in Embryophytes: Their evolution, ontogeny and interpretation. Taxon 28:117-132.

RASMUSSEN, H. 1981. Terminology and classification of stomata and stomatal development-a critical survey. Bot. Jour. Linn. Soc. 83:199-212.

SCHNEIDER, H., A. R. SMITH, AND K. M. PRYER. 2009. Is morphology really at odds with molecules in estimating fern phylogeny? Syst. Bot. 34:455-475.

TAKAHASHI, S., F. NAKAMURA, N. SAHASHI, T. OHMOTO, U. MIZOSHIMA, U. SANKAWA, AND G. H. N. TOWERS. 1990. Chemical markers of the Psilotaceae. Biochem. System. Ecol. 18:11-12.

TCHORZEWSKA, D., AND J. BEDNARA. 2011. The dynamics of the actin cytoskeleton during sporogenesis in Psilotum nudum $\mathrm{L}$. Protoplasma 248:289-298.

WANG, X., X. GAO, AND X. WANG. 2011. Stochastic dynamics of actin filaments in guard cells regulating chloroplast localization during stomatal movement Plant. Cell Environ. 34:1248-1257.

ZIMMERMANN, W. 1927. Die Spaltöffnungender Psilophyta und Psilotales. Zeitschr. F. Bot. 19:129-170. 